\title{
Inlet patch mimicking unstable angina pectoris
}

\author{
Tutkun Talih $^{1}$ (D), Ergin Arslan'1(D), Gamze Talih²(D), Mesut Sipahi' (iD) \\ ${ }^{1}$ Department of General Surgery, Bozok University School of Medicine, Yozgat, Turkey \\ ${ }^{2}$ Department of Anesthesiology and Reanimation, Bozok University School of Medicine, Yozgat, Turkey
}

\begin{abstract}
The ectopic stomach mucosa island in the proximal esophagus, which is generally known as the inlet patch or cervical inlet patch, is called as the heterotopic gastric mucosa of the esophagus. Despite its asymptomatic progress, it may cause chest pain, shortness of breath and difficulty in swallowing due to the acid secretion from the ectopic mucosa. The study aimed to present a patient who underwent coronary angiography with an unstable angina pectoris diagnosis by cardiologists for gastric chest pain but found an inlet patch in gastroduodenoscopy.
\end{abstract}

Keywords: Inlet patch, unstable angina pectoris, differential diagnosis

Cite this article as: Talih T, Arslan E, Talih G, Sipahi M. Inlet patch mimicking unstable angina pectoris. Turk J Surg 2020; 36 (2): 229-232.

\section{Corresponding Author}

Tutkun Talih

E-mail: tt3882@hotmail.com

Received: 23.03.2018

Accepted: 30.05 .2018

Available Online Date: 08.06 .2020

( C) Copyright 2020 by Turkish Surgical Society Available online at www.turkjsurg.com

DOI: 10.5578/turkjsurg.4165

\section{INTRODUCTION}

The heterotopic gastric mucosa (HGM) of the esophagus, also known as the inlet patch (IP), is a clinical entity described first in 1805 by Schmidt as the ectopic gastric mucosa located in the proximal esophagus (1). In the reported endoscopical studies, the incidence varies from less than $1 \%$ to $13.8 \%$. This rate increases to $70 \%$ in autopsy studies $(2,3)$. Although IP is generally considered as congenital, there are also those who think that it is acquired $(4,5)$.

Although most IPs are asymptomatic, they can cause chest pain and shortness of breath when they are acid-releasing (6). IP should be considered in the differential diagnosis of patients with chest pain complaints.

\section{CASE REPORT}

A 42-year-old male patient applied to our policlinic with complaints about cough, back pain and burning in stomach and throat ongoing for a long time. The patient said his complaints diminished after drinking anti acid syrups. The patient, who underwent in-depth anamnesis, said he applied to the emergency service of our hospital a week ago with severe chest pain, shortness of breath and excessive sweating. The patient did not have any underlying diseases and he smoked 2 packs of cigarettes a day and as his father also had a story of heart attack. The patient's enzyme and troponin were inspected at the emergency service. Although the results were normal and there was no problem in his electrocardiography, he was diagnosed with unstable angina pectoris and he was given urgent coronary angiography by the cardiology unit. The patient who had no problem following the treatment was discharged on the next day.

Upon this, after the patient was interviewed and the consent was obtained for gastroduodenoscopy, the procedure was performed under mild sedation. In gastroduodenoscopy, there were areas with erythema and oval-shaped, flat, velvety mucosa with approximately $0.5 \times 1 \mathrm{~cm}$ of perimeter in the esophagus at $20 \mathrm{~cm}$, which was separated from the peripheral esophageal tissue by sharp borders (Figure 1), and biopsy was taken from here. As there was doubt about the heterotopic gastric mucosa in the esophageal lesion and antral gastritis in the patient, proton pump inhibitor was administered to the patient. Pathologic result was chronic gastritis with mucous and 


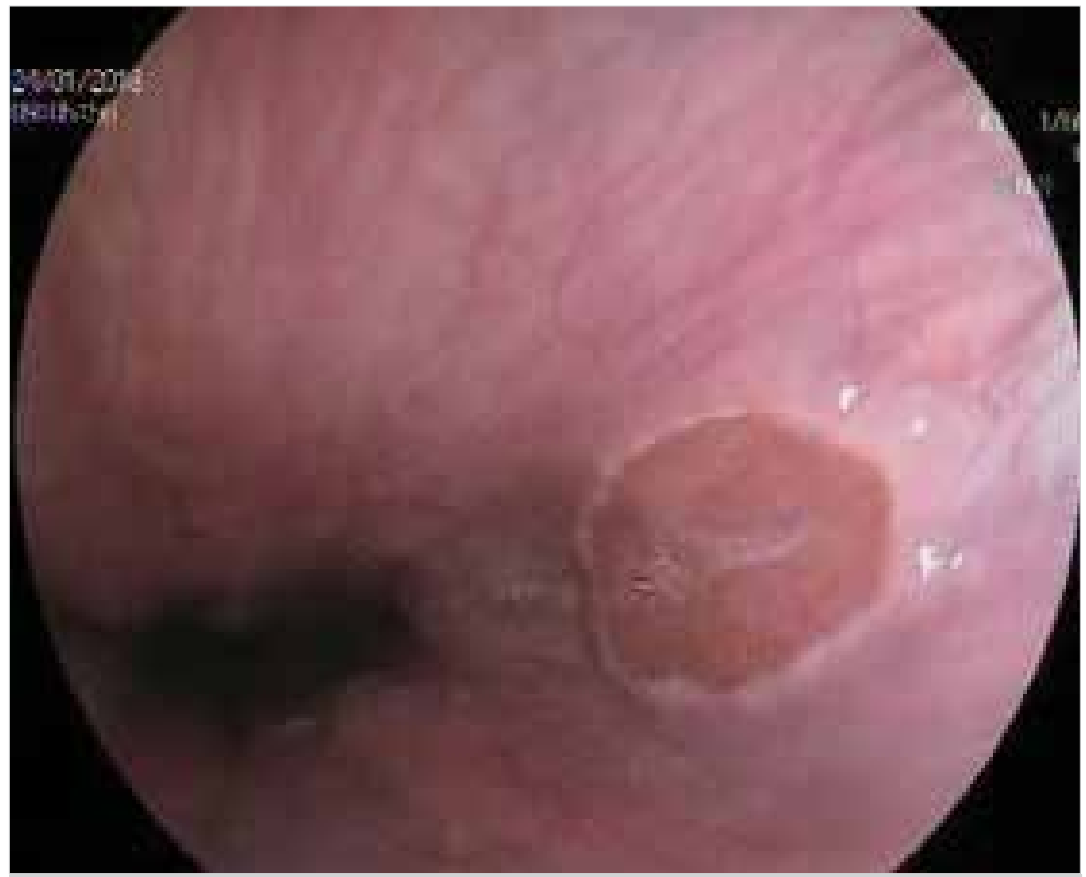

Figure 1. The endoscopic image of the oval-shaped, flat, velvety, heterotopic gastric mucosa which is separated from the peripheral oesophageal tissue by sharp borders.

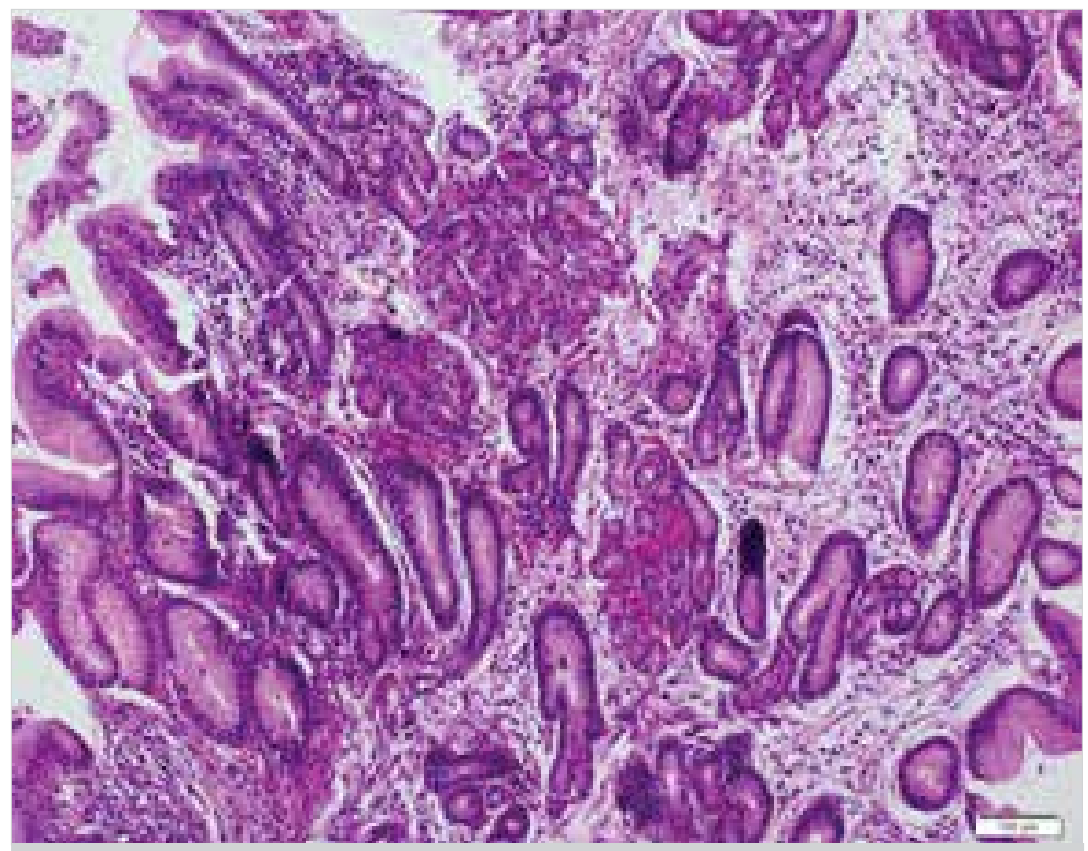

Figure 2. Typical IP image in which there are mucous and parietal cells in the photomicrograph (Haematoxylin eosin staining, original expansion $\times 100$ ).

parietal cells, and Helicobacter pylori were not observed in histology similar to the stomach corpus (Figure 2). These endoscopic and pathologic findings reminded us of HGM, to name in other words the IP, as the diagnosis.

\section{DISCUSSION}

Heterotopic gastric mucosa might be raised slightly from the surface, collapsed from the surface or flat, smooth surface or nodular. Microscopically, it is salmon-colored and velvety in ap- 
pearance, changing from 2-3 $\mathrm{mm}$ to $4.5 \mathrm{~cm}$ in size. It can be seen as a single piece or multiple pieces separated from the normal mucosa by sharp boundaries (7). We also conducted a biopsy with the pre-diagnosis of IP as we saw a smooth velvety area, separated by a sharp boundary from the mucosa in the $20^{\text {th }} \mathrm{cm}$ as described above while we were performing gastroduodenoscopy to our patient.

The most common histologic type of IP is cardia or oxyntic type of mucosa, and acid production can also be seen from the current gastric mucosa in some phenomena according to the type of the mucosa below. In some patients, laryngopharyngeal reflux is caused by the proximity to the upper esophageal sphincter (8). Helicobacter pylori colonization in IP is described up to $82 \%$ in some studies. Apart from that, atrophy, metaplasia, dysplasia and even carcinoma of HGM are described $(9,10)$. In the pathology result of our patient, cells similar to the stomach corpus were observed and helicobacter pylori and intestinal metaplasia were not observed.

Many of the cervical IPs are asymptomatic; however, esophagitis, ulcer and web, which are associated with acid secretion, and pain in the chest and throat, dysphagia, sensation of globus and dyspnea -as a result of contraction in the esophagus- may develop (6). Probably, our patient developed esophageal irritation dependent on acid secretion and in turn reflux symptoms and pain in the chest. Recurrent unstable angina pectoris symptoms of our patient lead cardiologists to coronary angiography. We are of the opinion that this case is important to expand the awareness of IP and evaluation of differential diagnosis of esophageal diseases in patients with angina pectoris by emergency physicians and cardiologists.

Informed Consent: Written informed consent was obtained from patient who participated in this case.

Peer-review: Externally peer-reviewed.

Author Contributions: Concept - T.T., E.A.; Design - T.T., G.T.; Supervision - T.T.; Materials - T.T.; Data Collection and/or Processing - T.T., M.S.; Analysis and/or Interpretation - T.T., E.A., M.S., G.T.; Literature Search - T.T., E.A.; Writing Manuscript - T.T., G.T.; Critical Reviews - T.T., M.S.
Conflict of Interest: No conflict of interest was declared by the authors.

Financial Disclosure: The authors declared that this study has received no financial support.

\section{REFERENCES}

1. Truong LD, Stroehlein JR, Mc Kechnie JC. Gastric heterotopia of the proximal esophagus and review of literature. Am J Gastroenterol 1986; 81: 1162-6. [CrossRef]

2. Von Rahden BH, Stein HJ, Becker K, Liebermann-Meffert D, Siewert JR. Heterotopic gastric mucosa of the esophagus: literature-review and proposal of a clinicopathologic classification. Am J Gastroenterol 2004; 99: 543-51. [CrossRef]

3. Chong VH. Heterotopic gastric mucosal patch of the proximal esophagus. In: Pascu O, editor. Gastrointestinal Endoscopy. Croatia: InTech Publishing; 2011.pp. 125-48. [CrossRef]

4. Avidan B, Sonnenberg A, Chejfec G, Schnell TG, Sontag SJ. Is there a link between cervical inlet patch and Barrett's esophagus? Gastrointest Endosc 2001; 53: 717-21. [CrossRef]

5. Meining A, Bajbouj M. Erupted cysts in the cervical esophagus result in gastric inlet patches. Gastrointest Endosc 2010; 72:603-5. [CrossRef]

6. Behrens C, Yen PP. Esophageal inlet patch. Radiol Res Pract 2011; 2011: 460890. [CrossRef]

7. Chong Heng V. Clinical significance of heterotopic gastric mucosal patch of the proximal esophagus. World J Gastroenterol 2013; 19: 331 8. [CrossRef]

8. Kim EA, Kang DH, Cho HS, Park DK, Kim YK, Park HC, et al. Acid secretion from a heteroptopic gastric mucosa in the upper esophagus demonstrated by dual probe 24-hour ambulatory $\mathrm{pH}$ monitoring. Korean J Intern Med 2001; 16: 14-7. [CrossRef]

9. Korkut E, Bektas M, Alkan M, Ustün Y, Meco C, Ozden A, et al. Esophageal motility and $24 \mathrm{~h} \mathrm{pH}$ profiles of patients with heterotopic gatsric mucosa in the cervical esophagus. Eur J Intern Med 2010; 21: 21-4. [CrossRef]

10. Akbayır N, Alkim C, Erdem L, Sökmen HM, Sungun A, Başak T, et al. Heterotopic gastric mucosa in the servical esophagus (inlet patch): endoscopic prevalence, histological and clinical characteristics. J Gastroenterol Hepatol 2004; 19: 934-8. [CrossRef] 
OLGU SUNUMU-ÖZET

Turk J Surg 2020; 36 (2): 229-232

\section{Unstabil anjina pektorisi taklit eden inlet patch olgusu}

Tutkun Talih ${ }^{1}$, Ergin Arslan ${ }^{1}$, Gamze Talih², Mesut Sipahi ${ }^{1}$

1 Bozok Üniversitesi Tıp Fakültesi, Genel Cerrahi Anabilim Dalı, Yozgat, Türkiye

${ }^{2}$ Bozok Üniversitesi Tıp Fakültesi, Anesteziyoloji ve Reanimasyon Anabilim Dalı, Yozgat, Türkiye

ÖZET

Genellikle inlet patch ya da servikal inlet patch olarak bilinen proksimal özofagustaki ektopik mide mukozası adası, yemek borusunun heterotopik mide mukozası olarak adlandırılır. Asemptomatik olmasına rağmen, göğüs ağrısına, nefes darlığına ve ektopik mukozanın asit sekresyonuna bağlı yutma güçlüğüne neden olabilir. Sırta vuran göğüs ağrısı nedeniyle kardiyologlar tarafından unstabil anjina pektoris ön tanısıyla koroner anjiyografi yapılan fakat gastroduodenoskopisinde inlet patch tespit edilen hasta sunulmuştur.

Anahtar Kelimeler: Inlet patch, unstabil anjina pektoris, ayırıcı tanı

Doi: $10.5578 /$ turkjsurg.4165 